\title{
Cell death signaling mechanisms in cardiac failure caused by magnesium deficiency: relationship to etiology of atherogenesis and sudden death ischemic heart disease
}

Keywords: heart disease, cardiovascular disease, autophagy, cardiac cells, coronary and cerebral blood vessels

\section{Introduction}

Globally, cardiovascular disease (CVD) is the number-one cause of deaths. Despite intensive research over the past 100 years, CV is on the rise in most countries. CVD is resulting in extremely high costs for treatment and hospitalization. Although many different pathways are now known to play important roles in death of cardiac cells via diverse molecular mechanisms, drugs are becoming costlier and costlier to the point that most countries can no longer afford the monies needed for prevention and treatment of CVD. Due to the aging population, globally, these costs will be prohibitive in most societies in the near future.

A major reason for inadequate prevention and treatment is, most likely, the diverse molecular mechanisms of programmed cardiac cell death. ${ }^{1,2}$ At least four of these pathways, i.e., apoptosis, necroptosis, pyroptosis, and ferroptosis, appear to be pivotal in cardiac cell death found in myocardial infarctions (MI), ischemic heart disease (IHD), congestive heart failure (CHF), and sudden-death ischemic heart disease (SDIHD).$^{3-5}$ Another pathway which originally was thought to be a protective pathway, namely autophagy, has recently been found to contribute to cardiac cell death if this pathway is over activated. 6,7

More than 50 years ago, two of us first provided experimental and clinical evidence that an overt, growing worldwide magnesium deficiency $(\mathrm{MgD})$ may be an underlying major factor via its direct actions on coronary and cerebral arterial and arteriolar blood vessels. ${ }^{8-18}$ Over the past 40 years, numerous investigators have found evidence to support our hypothesis. ${ }^{19-25}$ Originally, we thought the major reason for death from MI, IHD, and SDIHD was a greater and greater coronary and cerebral arteriolar and arterial vasoconstriction, thus reducing nutrition and oxygenation of the coronary and cerebral micro vasculatures. ${ }^{10,12-16,17,26}$ However, our research over the past 40 years, in conjunction with the work of other investigators, has made this original, simple idea much more complicated. Below, we review how the original idea of arteriolar and arterial vasoconstriction sets into motion (i.e., triggers) a massive series of molecular and cellular pathways leading to the diverse forms of programmed cell death and autophagy mentioned above.

Mg deficiency puts the squeeze on coronary and cerebral blood vessels

An early report from our laboratories suggested a progressive dietary and/or metabolic-induced loss of $\mathrm{Mg}$ during early developmental stages of life, particularly in coronary arteries could lead to coronary arterial vasospasm (CAV), ischemic heart disease (IHD), and suddendeath ischemic heart disease (SDIHD). ${ }^{11,12}$ Autopsy-driven results
Volume 5 Issue 2 - 2020

\author{
Burton MAltura, ${ }^{1-7}$ Asefa Gebrewold,' \\ Anthony Carella,' Nilank C Shah, ${ }^{1,5,6}$ Gatha \\ J Shah, ${ }^{1,5,6}$ Lawrence M Resnick, ${ }^{8}$ Sara M \\ Handwerker, ${ }^{9}$ Bella T Altura, ${ }^{1,3-7}$ \\ 'Department of Physiology and Pharmacology, State University \\ of New York Downstate Medical Center, USA \\ ${ }^{2}$ Department of Medicine, State University of New York \\ Downstate Medical Center, USA \\ ${ }^{3}$ Cardiovascular and Muscle Research, State University of New \\ York Downstate Medical Center, USA \\ ${ }^{4}$ The School of Graduate Studies in Molecular and Cellular \\ Science, The State University of New York Downstate Medical \\ Center, USA \\ ${ }^{5}$ Bio-Defense Systems, Inc, Rockville Centre, USA \\ ${ }^{6}$ Orient Biomedica, Estero, USA \\ ${ }^{7}$ Magnesium for Health Foundation, Patterson, USA \\ ${ }^{8}$ Department of Medicine, Cornell University College of \\ Medicine, USA \\ 'Department of Ob-Gyn, Mt. Sinai School of Medicine, USA
}

Correspondence: Professor Altura BM, Department of Physiology, Pharmacology \& Medicine, State University of New York, Downstate Medical Center, Brooklyn, New York II 203. USA, Tel 7I8-270-2194, Email baltura@downstate.edu

Received: June 07, 2020 | Published: June 30, 2020

from children who died due to accidental causes have been reported which show early signs of atherogenesis (i.e., fatty streaks on the walls of the aorta and carotid arteries) in young children as early as six years of age. ${ }^{27}$

Approximately 30 years ago, two of us using newly-developed selective ion-electrodes to measure blood, plasma and serum ionized $\mathrm{Mg}$ tested on some 35 cardiac patients presenting with Prinzmetal angina found, on average, a 35-40\% decrease in the ionized $\mathrm{Mg}$ blood fraction with almost no change in the total $\mathrm{Mg}$ fraction; ${ }^{28-30}$ cellular $\mathrm{Mg}^{2+}$ measured with ${ }^{31} \mathrm{P}$-nuclear magnetic resonance spectroscopy fell in parallel to the fall in serum ionized $\mathrm{Mg}$ (Table 1). What is very important about these results is that ever since Dr. William Heberden's findings in 1768, it has been known that Prinzmetal angina is a result of coronary arterial vasospasm. ${ }^{31}$ So, it is very difficult to not associate our clinical findings on these cardiac patients with anything but coronary arterial vasospasm. Moreover, we have reported that when coronary arterial vessels are placed in contact with low concentrations of $\mathrm{Mg}^{2+}$, they go into intense vasospasm; the lower the $\mathrm{Mg}^{2+}$ concentration, the greater the vasospasm. ${ }^{11,12}$ Moreover, in the presence of circulating neurohumoral agents (e.g., norepinephrine, angiotensin II, numerous vasoactive peptides), the coronary arterial spasms become larger (obviously being potentiated 
in strength). ${ }^{12,14}$ In addition, using ${ }^{31} \mathrm{P}$-nuclear magnetic resonance spectroscopy $\left({ }^{31} \mathrm{P}-\mathrm{NMRS}\right)$ and perfused rat hearts, we confirmed that just reducing the $\mathrm{Mg}^{2+}$, in the perfusates, caused reduced cardiac levels of ATP, ADP, and $\mathrm{Mg}^{2+}$, along with elevations in hydrogen ion concentration and inorganic phosphate combined with reductions in cardiac output, reduced ventricular contraction and reductions in coronary flows. ${ }^{32,33}$ Thus, we strongly believe, with such experimental and clinical biochemical observations low blood, tissue and cellular data, "Mg deficiency puts the squeeze on coronary arteries". Similar observations have been made by our group on isolated cerebral arteries and intact cerebral and medullary blood vessels. ${ }^{34-36}$

Table I Serum and red blood cell ionized $\mathrm{mg}$ in 35 prinzmetal patients

\begin{tabular}{lll} 
& Serum, mM/I & RBC, uM \\
\hline Controls & $0.69+/-0.08$ & $310+/-18$ \\
Patients & $0.52+/-0.04$ & $275+/-10$
\end{tabular}

All values are means +/- S.E.M. Patient values are significantly different from age-matched male controls $(\mathrm{P}<0.05)$.

Irregularities in daily diets are known to induce inflammatory lesions, which are believed to mediate the initiation process of atherogenesis..$^{37,38}$ Further, the same dietary disturbances have been reported to promote lipid deposition and accelerate the growth and transformation of the smooth muscle cells in the vascular walls. We have found that dietary deficiency of $\mathrm{Mg}$ in rabbits accelerates lipid deposition and plaques on the arterial walls. ${ }^{39}$ However, if we maintained microcirculatory blood flow and nutritive peripheral arterial and arteriolar blood flows, despite $\mathrm{Mg}$ deficiency, the lipid deposition and plaque depositions were reduced. ${ }^{40}$ So, we believe maintenance of microcirculatory blood flows (and thus, prevention/ amelioration of vasospasms) is an important key to amelioration of the CAV and inflammations required for atherogenesis, IHD and SDIHD. Upon close examination of the coronary and aortic arterial smooth muscle cells of the rats and rabbits fed low $\mathrm{Mg}$ diets, and using transmission EM, we noticed some strange morphological alterations akin to apoptosis, necroptosis, ferroptosis, and pyroptosis in different cells. ${ }^{41-44}$

\section{Regulated necroptosis, ferroptosis, and pyroptosis as well as apoptosis found in vascular smooth muscle cells of animals fed low Mg diets}

\section{Necroptosis}

Recently, a new form of cell death has been found which combines both necrosis and apoptosis termed "necroptosis". ${ }^{1-3}$ Necroptosis is tightly regulated by a group of characteristic signaling pathways and requires activation by two major enzyme receptor-interacting protein kinases, RIPK1 and RIPK3. ${ }^{3}$ Different cytokines have been found to participate in the cell death response produced by these kinases. ${ }^{1-3}$ Necroptosis has been proposed as a major component in the pathology of heart diseases, atherosclerosis, myocardial infarction, and cardiac remodeling. ${ }^{1-3}$ Morphologically, necroptosis is characterized by increases in cell volume and swelling of cell organelles (i.e., mitochondria, Golgi, and ER, etc). ${ }^{3}$ Using transmission EM, and Mg-deficient animals (dietary deficiency for 21 days), and excised ventricular myocytes, peripheral and cerebral arterial cells, we noted that some of these cells demonstrated rupture of plasma membranes, swelling of cell organelles (i.e., mitochondria,
Golgi, and ER), characteristic signs of necroptosis. ${ }^{41}$ ELISA assays clearly demonstrated activation of RIPK3, thus proving necroptosis was activated in the diverse cardiac and arterial myocytes of the Mg-deficient animals. ${ }^{41}$ Interestingly, treatment of the Mg-deficient animals with an inhibitor of RIPK3, viz., necrostatin -1 reduced the activation of NF-kB; NF-kB inhibition is known to reduce necroptosis. Overall, our new data would suggest that activation of necroptosis probably plays an important role in inflammation and atherogenesis seen in experimentally-induced cardiac and vascular diseases.

\section{Pyroptosis}

Another recently-discovered form of regulated cell death, viz., pyroptosis, has been implicated in atherosclerosis. ${ }^{4}$ Pyroptosis is dependent upon activation of several inflammatory proteases that are part of the family of cysteine-dependent aspartate-specific proteases (caspases). ${ }^{4}$ Morphologically, pyroptosis is different from apoptosis and necroptosis. Characteristically, pyroptosis demonstrates rapid plasma membrane rupture, release of intracellular contents, activation of caspase-1 (ELISA assays) and release of proinflammatory mediators, e.g., IL-1beta,IL-18, but usually no loss of mitochondrial contents. ${ }^{4}$ Examination of cardiac and arterial myocytes from the 21-day Mg-deficient animals revealed that some of these myocytes showed these characteristic signs of pyroptosis. ${ }^{43}$ Examination of coronary arterial tissues from patients undergoing bypass surgery in our hospitals revealed falls in serum ionized $\mathrm{Mg}$ and intracellular free Mg contents of red blood cells (Table 2), elevated serum IL-1beta, IL-18 and caspase-1, thus suggesting that many of the arterial cells underwent pyroptosis. ${ }^{43,44}$ Scanning EM of several of the arterial muscle cells of these bypass patients showed distinct, characteristic signs of ruptured plasma membranes. ${ }^{45}$

Table 2 Serum and red blood cell ionized mg levels in coronary by-pass patients

\begin{tabular}{lll}
\hline & Serum, mM/I & RBC, uM \\
\hline Controls & $0.68+/-0.06$ & $314+/-0.12$ \\
Patients & $0.54+/-0.06$ & $268+/-0.08$
\end{tabular}

All values are means +/- S.E.M. Patient values are significantly different from age-matched male patients $(P<0.05)$.

\section{Ferroptosis}

Another form of regulated $\mathrm{CD}$ which has gained considerable attention is iron-dependent, i.e., ferroptosis. ${ }^{1,2,5}$ Ferroptosis has been found in the pathogenesis of some cancers, tissue injuries, cell inflammations, and T-cell immunity. ${ }^{1,2,5}$ Unlike apoptosis or necroptosis, there are no membrane ruptures or nuclear condensations. Ferroptosis is characterized by mitochondrial abnormalities such as smaller than normal mitochondria, dissolution of mitochondrial cristae with ruptures, and increased mitochondrial outer membrane density with ruptures. ${ }^{5}$ Using cardiomyocytes and arterial smooth muscle cells, from living rats placed on Mg-deficient diets for 21 days, we found that the mitochondrial membranes were broken in many cells and showed loss of cristae, characteristic of ferroptosis. ${ }^{42,44}$ Application of histochemical staining to detect membrane iron (i.e., acid ferrocyanide and ammonium sulfate), we noted areas of the Mgdeficient cells to contain deposits of non-heme iron, a clear sign of ferroptosis. ${ }^{42,44}$ It is important to point-out here that a major property of iron-loaded cells is this causes accumulation and release of hydroxyl 
free radicals through the Fenton reaction or the iron-catalyzed HaberWeiss reaction in the presence of $\mathrm{H}_{2} \mathrm{O}_{2}$ or $\mathrm{O}_{2} .{ }^{5}$ We and others have shown that $\mathrm{Mg}$-deficiency in cardiovascular tissues from $\mathrm{Mg}$-deficient animals accumulate numerous free radicals. ${ }^{46-51}$ In earlier studies from our laboratories we showed that short-term $\mathrm{Mg}$ deficiency results in an up-regulation of $\mathrm{p} 53^{52}$ which is known to initiate ferroptosis. ${ }^{5}$

Recent studies by our group have reported that two ferroptosis inhibitors, ferrostatin-1 and liproxstatin-1, prevent $\mathrm{CD}$ and mitochondrial dysfunction, and $\mathrm{CD}$ induced by low $\mathrm{Mg}$, thus linking ferroptosis to the mitochondrial damage observed in the cardiovascular cells and tissues. ${ }^{42,44}$

\section{Mg deficiency and autophagy in cell death}

Accumulating evidence is mounting to implicate a cell death process, autophagy, in many diseases. ${ }^{6,7}$ This process involves a catabolic pathway that involves a turnover of long-lived proteins and organelles via lysosomal degradation. ${ }^{6,7}$ In cardiac tissues, this pathway plays an important pro-survival role during cellular stresses by extirpating protein aggregates and damaged organelles, thus preventing ischemic events. ${ }^{6,7}$ But, when severely-triggered, reperfusion can lead to cardiac failure and $\mathrm{CD} .{ }^{6,7}$ The hallmark of autophagy is de novo formation of autophagosomes. ${ }^{6,7}$

Tumor necrosis factor-alpha (TNF-alpha), which we have reported to be up-regulated in Mg-deficient animals,${ }^{53}$ induces an upregulation of beclin 1 (which we found up-regulated in Mg-deficient animals) [unpublished findings] activates coronary and aortic vascular smooth muscle autophagy. ${ }^{44,54}$ Many atherosclerotic plaques demonstrate autophagy. ${ }^{6,7}$ Damaged (and disintegrating) vascular smooth muscle cells in atherosclerotic plaques demonstrate several signs of autophagy in both humans and our Mg-deficient cholesterolfed rabbits. ${ }^{6,740,54}$ In our latter Mg-deficient rabbit atherosclerotic models, we have found plaques on coronary arteries and aortas that contain characteristic autophagic proteins, i.e., Atg 1 and Atg 13. ${ }^{54}$ Autophagic cell death is known to be caused by activation of the Atg 1-Atg 13 pathway. ${ }^{6,7}$ Although it is not yet known what is the precise pathway(s)-mechanisms for induction of autophagic $\mathrm{CD}$, we believe that our morphologic and biochemical data, so far, point to $\mathrm{Mg}$ deficiency as an important trigger for autophagic $\mathrm{CD}$, at least in experimental animals.

\section{Conclusions and future thoughts}

During the past decade, a considerable amount of experimental and clinical data has appeared to implicate several cell death pathways in the etiology of cardiovascular diseases such as atherogenesis, ischemic heart disease, hypertension, and sudden death ischemic heart disease. Epigenesis is a growing factor as a link between several of these cell death pathways and alterations in structural and morphogenetic alterations in cardiac and vascular muscle pathways and developmental disease processes. More than 50 years ago, two of us found that reductions in ionized $\mathrm{Mg}$ levels, both in-vivo and in-vitro, would cause coronary, cerebral, peripheral and uterine blood vessels to go into spasm and demonstrate increases in vascular reactivity to neuro-humoral constrictor agents and circulating vasopeptides. Dietary deficiency in rats resulted in methylation of DNA, histone modifications, increased tissue levels of certain micro-RNAs, and oxidation of DNA as well as down-regulation in telomerases in cardiac and vascular muscle cells. Use of specificallydesigned, sensitive electrodes for measurement of blood ionized $\mathrm{Mg}$ levels, in both humans and experimental animals, we found evidence to demonstrate that pregnant women show reductions in blood levels of $\mathrm{Mg}^{2+}$ towards term with some women who developed transient hypertension and gestational diabetes. Drug-resistant hypertensive patients and Mg-deficient animals exhibit increase in high blood pressure with concomitant increased pulse pressure and show structural/morphogenetic alterations in both cardiac and vascular muscle cells with atherogenesis. Careful investigation of these muscle cells, using transmission electron microscopy, showed that many of these cells were undergoing different forms of cell death: apoptosis, necroptosis, pyroptosis, ferroptosis, and/or autophagy. We believe our new studies provide presumptive evidence that dietary Mg deficiency can lead to epigenetic alterations in cardiac and vascular muscle phenotypic alterations which could induce cardiovascular diseases such as atherosclerosis, drug-resistant hypertension, diabetes mellitus, ischemic heart disease, preeclampsia-eclampsia, and sudden-death ischemic heart disease. In view of our studies, all pregnant mothers and babies should be monitored for ionized $\mathrm{Mg}$ levels and treated accordingly.

\section{Acknowledgments}

Much of our animal and human studies were supported, in part, by research grants from The National Institutes (i.e., National Heart, Lung and Blood Institute; National Institute on Mental Health; National Institute of Drug Abuse; and The National Institute on Alcoholism and Alcohol Abuse); The National Science Foundation; and unrestricted research grants from several pharmaceutical companies. Our original studies could not have been done without the help of some fantastic, young people (i.e., Jane Hanley, CarmelloParillo, and Collete Thaw).

\section{Conflicts of interest}

The author declares there are no conflicts of interest.

\section{References}

1. Konstantinidis K, Whelan RS, Kitsis RN. Mechanisms of cell death in heart disease. Arterioscler ThrombVasc Biol. 2012;32(7):1552-1562.

2. Mishra PK, Adameova A, Hill JA, et al Guidelines for evaluating myocardial cell death. Am $J$ Physiol Heart Circ Physiol. 2019;317(5):H891-H922.

3. Adameova A, Goncalvesova E, Szobi A, et al. Necroptotic cell death in failing heart: relevance and proposed mechanisms. Heart Failure Rev. 2016;21(2):213-221.

4. Zeng C, Wang R, Tan H. Role of pyroptosis in cardiovascular diseases and its therapeutic implications. Int J Biol Sci. 2019;15(7):1345-1357.

5. Kobayashi M, Suhara T, Baba Y, et al. Pathological roles of iron in cardiovascular diseases. Current Drug Targets. 2018;19(9):1068-1076.

6. De Meyer GRY, De Keulenaer GW, Martinet W. Role of autophagy in heart failure associated with aging. Heart Failure Rev. 2010;15(5):423-430.

7. Schiattarella G, Hill JA. Therapeutic targeting of autophagy in cardiovascular diseases. J Mol Cell Cardiol. 2016;95:86-93.

8. Altura BM, Altura BT. Influence of magnesium on druginduced contraction and ion content in rabbit aorta. Am J Physiol. 1971;220(4):938-944.

9. Altura BM, Altura BT. Magnesium and contraction of arterial smooth muscle. Microvasc Res. 1974;7(2):145-155. 
10. Altura BM, Altura BT. Magnesium and vascular tone and reactivity Blood Vessels. 1978;15(1-3):5-16.

11. Altura BM. Sudden-death ischemic heart disease and dietary magnesium intake: Is the target site coronary vascular smooth muscle? Med Hypoth. 1979;5(8):843-849.

12. Turlapty PDMV, Altura BM. Magnesium deficiency produces spasms of coronary arteries: relationship to etiology of suddendeath ischemic heart disease. Science. 1980;208(4440):198-200.

13. Altura BT, Altura BM. Withdrawal of magnesium causes vasospasm while elevated magnesium produces relaxation of tone in cerebral arteries. Neurosci Lett. 1980;20(3):323-327.

14. Altura BM, Turlapaty PDMV. Withdrawal of magnesium enhances coronary arterial spasmsproduced by vasoactive agents. $\mathrm{Br} J$ Pharmacol. 1982;77(4):649-659.

15. Altura BM, Altura BT, Carella A. Magnesium deficiency-induced spasms of umbilical vessels: relation to preeclampsia, hypertension, growth retardation. Science. 1983;221(4608):376-378.

16. Altura BM, Altura BT, Gebrewold A, et al. Magnesium deficiency and hypertension: correlationbetween magnesium deficiency and microcirculatory changes in situ. Science. 1984;223:1315-1317.

17. Altura BM, Altura BT. Magnesium, electrolyte transport and coronary vascular tone. Drugs. 1984;28(suppl1):120-142.

18. Altura BT, Altura BM. Cardiovascular actions of magnesium: Importance in etiology and treatment of high blood pressure. Magnesium-Bull. 1987;9:6-21.

19. Kimura T, Yasue H, Sakaino N, et al. Effects of magnesium on the tone of isolated human coronary arteries. Circulation. 1989;79(5):1118-1124.

20. Goto K, Yasue H, Okumura K, et al. Magnesium deficiency detected by intravenous loading test in variant angina pectoris. Am J Cardiol. 1990;65(11):709-712.

21. Simko F. Pathophysiological aspects of the protective effect of magnesium in myocardial infarction(review). Acta Med Hung. 1994;50(1-2):55-64.

22. Satake K, Lee JD, Shimizu H, et al. Relation between severity of magnesium deficiency and frequency of anginal attacks in men with variant angina. J Am Coll Cardiol. 1996;28(4):897-902.

23. Laurant P, Hayoz D, Brunner HR, et al. Effect of magnesium deficiency on blood pressure and mechanical properties of rat carotidartery. Hypertension. 1999;33:1105-1110.

24. Sueda S, Fukuda H, Watanabe K, et al. Magnesium deficiency in patients with recent myocardial infarction and provoked coronary artery spasm. J Jap Circ. 2001;65(7):643-648.

25. Minato N, Katayama Sakaguchi M, et al. Perioperative coronary artery spasm in off-pump coronary bypass grafting and its possible relation with perioperative hypomagnesemia. Ann Thoracic Cardiovasc Surg. 2006;12(1):32-36.

26. Altura BM, Altura BT, Gebrewold A, et al. Noise-induced hypertension and magnesium in rats:relationship to microcirculation and calcium. $J$ Appl Physiol. 1992;72(1):291-202.

27. Berenson GS, Srinivasan SR, Bao W, et al. Association between multiple cardiovascular risk factors and atherosclerosis in children and young adults. The Bogalusa Heart Study. New Engl J Med. 1998;338:1650-1656.

28. Altura BT, Altura BM. Measurement of ionized magnesium in whole blood, plasma and serum with a new ion-selective electrode in healthy and diseased human subjects. Magnes Trace Elem. 1991;10(2-4):9098.
29. Altura BT, Shirey TL, Young CC, et al. A new method for the rapid determination of ionized $\mathrm{Mg}^{2+}$ in whole blood, serum and plasma Methods Find Exp Clin Pharmacol. 1991;14(4):297-304.

30. Altura BT, Shirey TL, Young CC, et al. Characterization andstudies of a newelectrode forfree extracellular magnesium ions in whole blood, plasma and serum. In: Orazio P, Burritt MF, editors. Electrodes, Blood Gases and Other Critical Analytes: The Patient, the Measurement, and The Government. 1992;152-173.

31. Sternbach G. William Heberden and Myron Prinzmetal: angina pectoris. J Emerg Med. 1991;9(1-2):81-83.

32. Barbour RL, Altura BM, Reiner SD, et al. Influence of $\mathrm{Mg}^{2+}$ on cardiac performance, intracellular free $\mathrm{Mg}$ and $\mathrm{pH}$ in perfused hearts as assessed with ${ }^{31} \mathrm{P}-\mathrm{NMR}$ spectroscopy. Magnes Trace Elem. 1992;10(24):99-116.

33. Altura BM, Barbour RL, Dowd TL, et al. Low extracellular magnesium induces intracellular free $\mathrm{Mg}$ deficits, ischemia, depletion of highenergy phosphates and cardiac failure in intact working rat hearts: $\mathrm{A}^{3}$ P-NMR study. BiochimBiophys Acta. 1993;1182(3):328-332.

34. Altura BM, Altura BT. Role of magnesium and calcium in alcoholinduced hypertension and strokes as probed by in-vivo television microscopy, digital image microscopy, optical spectroscopy and a unique magnesium ion-selective electrode. Alcoholism: Clin Exp Res. 1994;18(5):1057-1068.

35. Altura BM, Gebrewold A, Zhang A, et al. Short-term reduction in dietary intake of magnesium causes deficits in brain intracellular free $\mathrm{Mg}^{2+}$ and $\left[\mathrm{H}^{+}\right]_{\mathrm{I}}$ but not high-energy phosphates as observed by in-vivo ${ }^{31}$ P-NMR. BiochimBiophys Acta. 1997;1358(1):1-5.

36. Altura BT, Memon ZS, Zhang A, et al. Low levels of serum ionized magnesium are found in stroke patients early after stroke which results in rapid elevation in cytosolic free calcium and spasm in cerebral vascular muscle cells. Neurosci Lett. 1997;230(1):37-40.

37. Kumar V, Abbas K, Fasuto N, et al. Robbins and Cotran Pathologic Basis of Disease, 8th ed. Saunders, Philadelphia. 2010;105-109.

38. Majno G, Joris I. Tissues, Cells and Disease. 2nd ed. Oxford Univ Press, New York. 2014

39. Altura BT, Brust M, Bloom S, et al. Magnesium dietary intake modulates blood lipid levels and atherogenesis. Proc Nat Acad Sci USA. 1990;87(5):1840-1844.

40. Altura BM, Shah NC, Shah GJ, et al. Magnesium deficiency, sphingolipids, and telomerase: Relevance to atherogenesis, cardiovascular disease, and aging. In: Preedy V, Vinood B, eds. Handbook of Famine, Starvation and Nutrient Deprivation. Springer Berlin. 2018

41. Altura BM, Shah NC, Shah GJ, et al. Regulated RIPK3 necroptosis is produced in cardiovascular tissues and cells in dietary magnesium deficiency: Roles of cytokines and their potential importance in inflammation and atherogenesis. J Med \& Surg Pathol. 2017;2(3).

42. Altura BM, Gebrewold A, Carella A, et al. Regulated ferroptosis cell death is produced in cardiovascular tissues and cells in dietary magnesium deficiency: Initiation of roles of glutathione, mitochondrial alterations and lipid peroxidation in inflammation and atherogenesis. EC Pharmacol Toxicol. 2018;6(7):535-541.

43. Altura BM, Gebrewold A, Carella A, et al. Regulated pyroptosis is produced in cardiovascular tissues and cells in dietary magnesium deficiency: Cross-talk with cytokines, PAF, telomerases and aging. EC Pharmacol Toxicol. 2019;7(11):25-30.

44. Shah NC, Shah GJ, Altura BT, et al. Transmission electron microscopy of cardiovascular tissues of rats fed diets low in magnesium reveals diverse forms of cell death. 2020 
45. Altura BM, Burack BL, Zisbrod Z, et al. Patients undergoing coronary artery bypass and serum ionized magnesium deficiency exhibit pyroptosis in excised tissues. 2020.

46. Altura BM, Gebrewold A, Zhang A, et al. Low extracellular magnesium ions induce lipid peroxidation and activation of nuclear factor kappa B in canine cerebral vascular smooth muscle : possible relation to brain injury and strokes. NeurosciLell. 2003;341(3):189-192.

47. Dickens BF, Weglicki WB, Li YS, et al. Magnesium deficiency in vitro enhances free radical -induced intracellular oxidation and cytotoxicity in endothelial cells. FEBS Lett. 1992;311(3):187-191.

48. Wu F, Altura BT, Gao J, et al. Ferrylmyoglobin formation induced by acute magnesium deficiency in perfused rat heart causes cardiac failure. BiochimBiophys Acta. 1994;1225:158-164.

49. Weglicki WB. Hypomagnesemia and inflammation: Clinical and basic aspects. Annu Rev Nutr. 2012;32:55-71.

50. Rayssiguier Y, Gueux E, Buissiere I, et al. Dietary magnesium susceptibility of lipoprotein and tissues to peroxidation in rats. $J \mathrm{Am}$ Coll Nutr. 1993;12(2):133-137.
51. Altura BM, Shah NC, Jiang XC, et al. Short-term magnesium deficiency results in decreased levels of serum sphingomyelin, lipid peroxidation, and apoptosis in cardiovascular tissues. Am J Physiol Heart Circ Heart Physiol. 2009;297(1):H86-H92.

52. Altura BM, Shah NC, Li Z, Jiang XC, et al. Short-term magnesium deficiency upregulates sphingomyelin synthesis and p53 in cardiovascular tissues and cells: relevance to the de novo synthesis of ceramide. Am J Physiol Heart Circ Physiol. 2010;299(6):H2046-2055.

53. Altura BM, Shah NC, Shah GJ, et al. Short-term magnesium deficiency upregulates ceramide synthase in cardiovascular tissues and cells: cross-talk among cytokines, $\mathrm{Mg}^{2+}, \mathrm{NF}-\mathrm{kB}$ and de novo ceramide. $\mathrm{Am} \mathrm{J}$ Physiol Heart Circ Physiol. 2012;302(1):H319-H332.

54. Altura BT, Brust M, Stempak M, et al. Magnesium deficiency in rabbits produces autophagy in plaques. 2020. 